\title{
Correction to: Hypotonicity-induced cell swelling activates TRPA1
}

\author{
Fumitaka Fujita ${ }^{1,2,4} \cdot$ Kunitoshi Uchida $^{1,3} \cdot$ Yasunori Takayama ${ }^{1,3} \cdot$ Yoshiro Suzuki $^{1,3} \cdot$ Masayuki Takaishi ${ }^{1,5}$. \\ Makoto Tominaga ${ }^{1,3,6}$
}

Published online: 8 February 2019

(C) The Author(s) 2019

\section{Correction to: J Physiol Sci (2018) 68:431-440 https://doi.org/10.1007/s12576-017-0545-9}

The article Hypotonicity-induced cell swelling activates TRPA1, written by Fumitaka Fujita, Kunitoshi Uchida, Yasunori Takayama, Yoshiro Suzuki, Masayuki Takaishi and Makoto Tominaga, was originally published electronically on the publisher's internet portal (currently SpringerLink) on 16 June 2017 without open access.

With the author(s)' decision to opt for Open Choice the copyright of the article changed on 28 January 2019 to $($ ) The Author(s) [Year] and the article is forthwith distributed under the terms of the Creative Commons Attribution 4.0 International License (http://creativecommons.org/licenses/ by/4.0/), which permits use, duplication, adaptation, distribution and reproduction in any medium or format, as long

The original article can be found online at https://doi.org/10.1007/ s12576-017-0545-9.

Fumitaka Fujita

fujita-f@mandom.co.jp

Makoto Tominaga

tominaga@nips.ac.jp

1 Division of Cell Signaling, Okazaki Institute for Integrative Bioscience (National Institute for Physiological Sciences), National Institutes of Natural Sciences, Okazaki, Aichi 444-8787, Japan

2 Basic Research Institute, Mandom Corp., Osaka 540-8530, Japan

3 Department of Physiological Sciences, SOKENDAI (The Graduate University for Advanced Studies), Okazaki, Aichi 444-8585, Japan

4 Laboratory of Advanced Cosmetic Science, Graduate School of Pharmaceutical Sciences, Osaka University, 1-6 Yamadaoka, Suita, Osaka 565-0871, Japan

5 Product Assurance Division, Mandom Corp., Osaka 540-8530, Japan

6 Institute for Environmental and Gender-Specific Medicine, Juntendo University, Tokyo 113-0033, Japan as you give appropriate credit to the original author(s) and the source, provide a link to the Creative Commons license and indicate if changes were made.

Open Access This article is distributed under the terms of the Creative Commons Attribution 4.0 International License (http://creativeco mmons.org/licenses/by/4.0/), which permits unrestricted use, distribution, and reproduction in any medium, provided you give appropriate credit to the original author(s) and the source, provide a link to the Creative Commons license, and indicate if changes were made. 